\title{
AN IMPROVING THE OCCUPATIONAL RISK ASSESSMENT IN INDUSTRIAL ENTERPRISES
}

doi: $10.2478 /$ czoto-2021-0027

Date of submission of the article to the Editor: 25/11/2020

Date of acceptance of the article by the Editor: 26/03/2021

\author{
Dominika Siwiec ${ }^{1}$ - orcid id: 0000-0002-6663-6621 \\ Artur Woźny ${ }^{1}$ - orcid id: 0000-0002-0294-0157 \\ Andrzej Pacana ${ }^{1}$ - orcid id: 0000-0003-1121-6352 \\ ${ }^{1}$ Rzeszów University of Technology, Poland
}

\begin{abstract}
An occupational risk assessment is one of the main processes to assure a safe and healthy workplace. It was shown, that this process is particularly important in the cause of industrial enterprises, in which the number of accidents is the largest. In these enterprises, one of the most often practiced methods is the PN-N-18002 method. However, it was concluded this method has some limitations. They concern the way of assessing the risks in the traditional number scale, which is less precise than the fuzzy triangular number (using in FAHP). Therefore, the aim is to improve the process of assessment in industrial enterprises by integrated the PN-N-18002 method with the FAHP method (Fuzzy Analytic Hierarchy Process). The test of the proposed method was made for three machine operator positions used to aggregate extraction in one of the Podkarpacie enterprises. These positions were: loader operator ( $Ł-34)$, digger operator (CAT 323), dredge operator (300/250 KREBS 10/8). The concept of the method was to identify in a precise way what is the greatest extent danger to the operators of these workplaces. It was shown, that it is the work at height. It was concluded, that this method can be practice to risk assessment of other workplaces, among others from industrial enterprises. The originality is the integrated risk assessment method (PN-N-18002) with the fuzzy multicriteria decision method (FAHP) as part of achieving the precise results of risk assessment.
\end{abstract}

Keywords: risk assessment, production engineering, mechanical engineering, fuzzy analytic hierarchy process, $\mathrm{PN}-\mathrm{N}-18002$

\section{INTRODUCTION}

Effective business management refers to carrying out an occupational risk assessment that contributes to productive work while ensuring a safe workplace (Woźny et al., 2016). A review of the literature on the subject indicates that occupational risk was assessed using methods applicable only to risk assessment, i.e. Risk Score (Harabas and Klimecka-Tatar, 2017; Saja et al., 2013) or the PN-N-18002 method (Duda and Juzek, 2018). Also, the occupation risk assessments were made by methods which are connecting the identification of the risk and their assessment, i.e. Event Tree Analysis 
(ETA) or Fault Tree Analysis (FTA) (Krause, 2011, Woźny and Pacana, 2013). Also, as part of the occupational risk assessment, the actions were taken, which the aim was improving this assessment. For example, Aagedal et al. (2002) proposed models supporting the realization of individual stages of occupational risk assessment and reporting the obtained results. In a turn of work (Karkoszka, 2009) it was presented the method which has application to meeting the legal requirements of the health and safety assessment and also was used the Event Tree Analysis as part of improving this process. Another example is an article of Karkoszka and Szewieczek (2007) in which the risk assessment was integrated with the context of different methods, for example: estimating of incompatibilities in a quality management system, management of environment or Health and Safety. Additionally, it was shown, that occupation risk assessment was carried out with the classical numeral scale, which is generating vague evaluations and thus imprecise results (Chen et al., 2020; Krishankumar et al., 2020; Siwiec, Bednarova and Pacana, 2020). After a review of selected literature items, it was concluded, that this aspect was not analyzed so far. Therefore, it was considered a research gap, and it was considered justified to improve the occupational risk assessment by eliminating the ambiguity of the assessments awarded in the process of risk assessment at the workplace.

It was assumed that the Fuzzy Analytic Hierarchy Process (FAHP or Fuzzy AHP) would be effective for this purpose (Solangi et al., 2020; Pacana et al., 2020; Pacana et al., 2018). This method, as shown by the authors of articles (for example Gil and GonzalezRodriguez, 2012), supports reducing the aforementioned ambiguities in assessments, by transforming the assessments in classical number scale on the triangular fuzzy numbers (Chang, 1996; Siwiec et al., 2020). Therefore, it was considered that using the FAHP to reduce the ambiguities in the stage of occupational risk assessment is legitimate. In a turn of the context of occupational risk assessment, the largest number of accidents in work in Poland in the $\mathbf{2 0 1 9}$ year were noted in enterprises from the industrial sector $(28,212$ accidents). Another example for which one of the largest numbers of accidents was recorded (i.e. 2,407 accidents) was, according to the GUS (Statistic Poland), the mining and quarrying section (GUS, 2020; Siwiec et al., 2019). In the mentioned industrial enterprises (and mining and quarrying section) one of the most often practice methods of occupational risk assessment is the PN-N-18002 method (Duda and Juzek, 2018). Therefore, legitimate is improving the occupational risk assessment performed by the $\mathrm{PN}-\mathrm{N}-18002$ method in the context of industrial enterprises. In view of it, the aim was to improve the process of assessment in industrial enterprises by integrated the PN-N-18002 method with the FAHP method (Fuzzy Analytic Hierarchy Process). The test of proposed integrated methods was made based on occupation risk assessment for three workplaces in one of Podkarpacie aggregate mining enterprises.

\section{METHODOLOGY OF RESEARCH}

As part of improving the occupation risk assessment in industrial enterprises, the method of occupation risk assessment PN-N-18002 was used, and then this method was integrated with the Fuzzy Analytic Hierarchy Process (Fuzzy AHP). The PN-N18002 method belongs to series of PN-N-18000 standards of occupational health and safety (Karkoszka, 2009) and its main application is an occupational risk assessment on workplaces (Bajdur and Idzikowski, 2012; Woźny and Pacana, 2013). In a turn, the FAHP method is one of the most often practice multicriteria decision methods, which 
allows for reducing inconsistencies in the assessments of decision-makers (Siwiec et al., 2020). The process of realization of the method is shown in 5 main steps.

The first step of the method is to choose the workplaces to occupation risk assessment according to the PN-N-18002 method. The choice depends on the individual preferences of the entity using the method. The second step of the method is to make the occupation risk assessment for the chosen workplace using the PN-N-18002 method. The way of making the PN-N-18002 method is shown for example literature i.e. (PN-N-18002:2011; Szklarzyk et al., 2016). After the occupation risk assessment by the PN-N-18002 method is made, it is possible to integrate the results with the FAHP method. It is shown in the next stage. The third step of the method is to transform the obtained occupational risk assessments on the triangular fuzzy numbers preferred by Saaty scale, i.e. 1-9, 1-7 or 1-5 (Siwiec et al., 2020). The choice of a set of scales depends on the individual preferences of the entity using the method. The fourth step of the method is to use the FAHP method. In this aim, initially, it is necessary to prepare the fuzzy matrix of pairwise comparisons $\tilde{A}=\left[\widetilde{a_{\imath \jmath}}\right]$, which concerns the unclear assessments in the process of occupational risk assessments. Then on the diagonal, there are always triangular values of the fuzzy number equal to $(1,1,1)$, while above the diagonal are the values of pairwise comparisons, and under the diagonal their reciprocal values. In the case of comparing several positions, a joint decision matrix should be created, according to the authors of the work (Tsai et al., 2020). The clear weights are successively calculated from the fuzzy matrix of pairwise comparisons (1) (Mir and Padma, 2016; Siwiec et al., 2020):

$$
S_{i}=\sum_{j=1}^{m} M_{i}^{j}\left[\sum_{i=1}^{n} \sum_{j=1}^{m} M_{i}^{j}\right]^{-1}
$$

To achieve $\left(\sum_{i=1}^{n} \sum_{j=1}^{m} M_{i}^{j}\right)^{-1}$ is necessary to fuzzy addition $M_{i}^{j}(j=1,2, \ldots, m)$ the values of matrix (2) (Mir and Padma, 2016; Siwiec et al., 2020):

$$
\sum_{i=1}^{n} \sum_{j=1}^{m} M_{i}^{j}=\left[\sum_{j=1}^{m} l_{j}, \sum_{j=1}^{m} m_{j}, \sum_{j=1}^{m} u_{j}\right]
$$

The reciprocal of the vector is (3) (Mir and Padma, 2016):

$$
\left[\frac{1}{\sum_{j=1}^{m} M_{i}^{j}}\right]=\left(\frac{1}{\sum_{i=1}^{n} u_{i}}, \frac{1}{\sum_{i=1}^{n} m_{i}}, \frac{1}{\sum_{i=1}^{n} l_{i}}\right)
$$

Subsequently, the smallest degree of possibility is calculated (4) (Mir and Padma, 2016; Siwiec et al., 2020):

$$
\begin{array}{cc}
1 & \text { if } m_{2} \geq m_{1} \\
0 & \text { if } l_{1} \geq u_{2} \\
\frac{l_{1}-u_{2}}{\left(m_{2}-u_{2}\right)-\left(m_{1}-l_{1}\right)} & \text { for otherwise }
\end{array}
$$

Then assuming that (5) (Mir and Padma, 2016):

$$
\begin{gathered}
V\left(M_{2} \geq M_{1}, M_{2}, \ldots, M_{k}\right)=V\left[\left(M \geq M_{1}\right)\right] \text { and } V\left[\left(M \geq M_{k}\right)\right]=\min V\left[\left(\mathrm{M} \geq \mathrm{M}_{\mathrm{i}}\right)\right] \\
\text { assumed that: } \mathrm{d}^{\prime}\left(\mathrm{A}_{\mathrm{i}}\right)=\operatorname{minV}\left(\mathrm{S}_{\mathrm{i}} \geq \mathrm{S}_{\mathrm{k}}\right) \text { for } \mathrm{k}=1,2, \ldots, \mathrm{n} ; \mathrm{k} \neq \mathrm{i}
\end{gathered}
$$

it is possible to define the vector as (6), and the normalized vector is (7) (Mir and Padma, 2016):

$$
W^{\prime}=\left(d^{\prime}\left(A_{1}\right), d^{\prime}\left(A_{2}\right), \ldots, d^{\prime}\left(A_{n}\right)\right)^{T}
$$




$$
W=\left(d\left(A_{1}\right), d\left(A_{2}\right), \ldots, d\left(A_{n}\right)\right)^{T}
$$

In the proposed method, the maximum value of the normalized vector relates to the greatest source of hazard at the analyzed workplace. The fifth stage is to identify the root of the largest danger in the analyzed workplace and making adequate improvement actions.

\section{RESULTS}

To test of proposed method the three machine operators stations, which were used in process of extraction of aggregates in one of Podkarpacie opencast enterprises. These were the positions of loader operator ( Ł-34), excavator operator (323) and dredge operator (300/250 KREBS 10/8). The motivation of choice of these positions was the biggest values of assessments of occupational risk which were obtained from all of the positions by the PN-N-18002 method. Also, these machines had a key share in the aggregate extraction process. For example, the excavator operator CAT 323 and the loader operator $\measuredangle-34$, dig and load aggregate for means of transport, and also it scoops and moves the lump of aggregate or top layer of earth. In a turn, the dredge operator $300 / 250$ KREBS 10/8, extracts aggregate working in a water body. The aim was to determine which source of risk is the greatest threat to the life and health of employees working in the positions selected for the analysis. The results of occupational risk assessment by $\mathrm{PN}-\mathrm{N}-18002$ for the operator of an excavator (E), dredgers (D) and loader $(\mathrm{L})$ is shown in Table 1.

Table 1

The results of occupational risk assessment by PN-N-18002

\begin{tabular}{|c|c|c|c|c|c|c|c|}
\hline \multirow[t]{2}{*}{$\begin{array}{l}\text { Source of } \\
\text { threat }\end{array}$} & \multirow[t]{2}{*}{ Threat } & \multirow[t]{2}{*}{ Protection } & \multicolumn{2}{|c|}{$\begin{array}{c}\text { Risk } \\
\text { category } \\
\text { adopted }\end{array}$} & \multicolumn{3}{|c|}{$\begin{array}{c}\text { Total } \\
\text { points in } \\
\text { the group }\end{array}$} \\
\hline & & & $\mathrm{L}$ & $E$ & $\bar{L}$ & $\mathrm{E}$ & $\mathrm{D}$ \\
\hline \multirow{5}{*}{ Machines } & \multirow{5}{*}{$\begin{array}{l}\text { Noise } \\
\text { during } \\
\text { plant } \\
\text { inspection }\end{array}$} & $\begin{array}{l}\text { Applied noise reduction measures } \\
\text { below } 85 \mathrm{~dB}(\mathrm{~A})\end{array}$ & 4 & 3 & \multirow{5}{*}{4} & \multirow{5}{*}{3} & \multirow{5}{*}{4} \\
\hline & & $\begin{array}{l}\text { NDN exceeding, noise above } 85 \\
\mathrm{~dB} \text {, hearing protectors used }\end{array}$ & - & - & & & \\
\hline & & $\begin{array}{l}\text { Noise above } 85 \mathrm{~dB} \text { - hearing } \\
\text { protectors are not used }\end{array}$ & - & - & & & \\
\hline & & Equivalent level $A$ to sound $L$ [dB] & 76.4 & 71.5 & & & \\
\hline & & Multiplicity & 0.14 & 0.04 & & & \\
\hline \multirow{5}{*}{$\begin{array}{l}\text { Machines. } \\
\text { production } \\
\text { process }\end{array}$} & \multirow{5}{*}{ Vibration } & General vibration & 0.380 & 0.145 & \multirow{5}{*}{4} & \multirow{5}{*}{2} & \multirow{5}{*}{4} \\
\hline & & Multiplicity & 0.47 & 0.18 & & & \\
\hline & & No mechanical vibrations & 1.02 & - & & & \\
\hline & & Local vibration & 0.36 & - & & & \\
\hline & & Multiplicity of the limit value OEL & 4 & - & & & \\
\hline \multirow{3}{*}{$\begin{array}{l}\text { Production } \\
\text { process }\end{array}$} & \multirow{3}{*}{$\begin{array}{l}\text { Petroleum } \\
\text { vapors }\end{array}$} & Possibility of overfilling diesel fuel & 3 & 3 & \multirow{3}{*}{3} & \multirow{3}{*}{3} & \multirow{3}{*}{3} \\
\hline & & No oil spill possible & - & - & & & \\
\hline & & Failure to apply security & - & - & & & \\
\hline \multirow{2}{*}{$\begin{array}{l}\text { Electric } \\
\text { lighting of } \\
\text { the } \\
\text { workplace }\end{array}$} & \multirow{2}{*}{$\begin{array}{l}\text { Electric } \\
\text { shock }\end{array}$} & Applied efficient fire protection & 4 & 2 & \multirow[b]{2}{*}{4} & \multirow[b]{2}{*}{2} & \multirow[b]{2}{*}{4} \\
\hline & & Applied efficient fire protection & - & - & & & \\
\hline
\end{tabular}




\begin{tabular}{|c|c|c|c|c|c|c|c|}
\hline \multirow{2}{*}{$\begin{array}{l}\text { Work at } \\
\text { height }\end{array}$} & \multirow{2}{*}{$\begin{array}{l}\text { Fall from } \\
\text { a height }\end{array}$} & $\begin{array}{l}\text { Use of personal protective } \\
\text { equipment against falls from a } \\
\text { height }\end{array}$ & 5 & 5 & \multirow[t]{2}{*}{5} & \multirow[t]{2}{*}{5} & \multirow[t]{2}{*}{5} \\
\hline & & $\begin{array}{l}\text { Failure to use personal protective } \\
\text { equipment }\end{array}$ & - & - & & & \\
\hline \multirow{2}{*}{$\begin{array}{l}\text { Work in } \\
\text { forced } \\
\text { position }\end{array}$} & \multirow[t]{2}{*}{ Fatigue } & $\begin{array}{l}\text { Use of facilities and auxiliary } \\
\text { equipment }\end{array}$ & - & - & \multirow[t]{2}{*}{4} & \multirow[t]{2}{*}{4} & \multirow[t]{2}{*}{4} \\
\hline & & Failure to use auxiliary equipment & 4 & 4 & & & \\
\hline \multirow{8}{*}{$\begin{array}{l}\text { Machines, } \\
\text { stationary } \\
\text { and } \\
\text { auxiliary } \\
\text { tools }\end{array}$} & \multirow{8}{*}{$\begin{array}{l}\text { Hit, Fall, } \\
\text { Slip }\end{array}$} & $\begin{array}{l}\text { Possibility of hitting with moving } \\
\text { parts of the machine (no guards) }\end{array}$ & 1 & 1 & 1 & 1 & 1 \\
\hline & & $\begin{array}{l}\text { Hazards related to sharp and } \\
\text { protruding parts }\end{array}$ & 3 & 3 & 3 & 3 & 2 \\
\hline & & $\begin{array}{l}\text { Hazards related to the movement } \\
\text { of people and equipment } \\
\text { (drowning) }\end{array}$ & 4 & 4 & 4 & 4 & 3 \\
\hline & & $\begin{array}{l}\text { Hazards related to the physical } \\
\text { properties of the material (weight, } \\
\text { sharp edges, slippery surfaces, } \\
\text { etc.) }\end{array}$ & 2 & 2 & 2 & 2 & 2 \\
\hline & & $\begin{array}{l}\text { Electric shock hazard Inadequate } \\
\text { electrical installation }\end{array}$ & 2 & 2 & 2 & 2 & 2 \\
\hline & & Threat in work in open space & 6 & 6 & 6 & 6 & 6 \\
\hline & & Burn hazard & 1 & 1 & 1 & 1 & 1 \\
\hline & & Risk of a person falling & 4 & 4 & 4 & 3 & 4 \\
\hline \multicolumn{5}{|c|}{ sum of points in III step of PN-N-18002 method } & 47 & 41 & 45 \\
\hline
\end{tabular}

Source: Unpublished materials of the aggregate mining plant located in Podkarpacie.

According to the occupation risk assessment by $\mathrm{PN}-\mathrm{N}-18002$ it was shown a small threat at analyzed workplaces, i.e.: loader operator $Ł-34$ (4.36 points), excavator operator 323 (3.39 points) and dredge operator 300/250 KREBS 10/8 (4.57 points). Because the assessments obtained for identified categories of risk at analyzed workplaces were similar, the legitimate was reducing the threat source analysis to a combined decision matrix (Table 2).

Table 2

An combined decision matrix

\begin{tabular}{|l|l|l|l|l|}
\hline Symbol & \multicolumn{1}{|c|}{ Source of threat } & $\mathbf{~}_{\mathbf{i j}}$ & $\boldsymbol{m}_{\mathbf{i j}}$ & $\boldsymbol{u}_{\mathbf{i j}}$ \\
\hline T1 & Machines & 2.00 & 3.63 & 5.00 \\
\hline T2 & Machines. production process & 1.00 & 3.17 & 5.00 \\
\hline T3 & Production process & 2.00 & 3.00 & 4.00 \\
\hline T4 & Electric lighting of the workplace & 1.00 & 3.17 & 5.00 \\
\hline T5 & Work at height & 4.00 & 5.00 & 6.00 \\
\hline T6 & Work in forced position & 3.00 & 4.00 & 5.00 \\
\hline T7 & Machines. stationary and auxiliary tools & 1.00 & 2.32 & 7.00 \\
\hline
\end{tabular}

Source: own study

Subsequently, a pairwise comparison matrix was created based on the combined decision matrix. The sum of the values for each row and the relative value of the fuzzy weight were successively calculated (Table 3 ). 
Table 3

Fragment of the pairwise comparison matrix and the results of the relative value of the fuzzy weight

\begin{tabular}{|c|c|c|c|c|}
\hline $\begin{array}{c}\text { Source of } \\
\text { threat }\end{array}$ & T1 & T2 & $\mathbf{l}_{\mathrm{ij}} ; \boldsymbol{m}_{\mathrm{ij}} ; \boldsymbol{u}_{\mathrm{ij}}$ & $\begin{array}{l}\text { Relative value of the } \\
\text { fuzzy weight }\end{array}$ \\
\hline T1 & $1.0 ; 1.0 ; 1.0$ & $2.0 ; 1.1 ; 1.0$ & $9.17 ; 7.70 ; 6.80$ & $0.17 ; 0.14 ; 0.10$ \\
\hline T2 & $0.5 ; 0.9 ; 1.0$ & $1.0 ; 1.0 ; 1.0$ & $4.58 ; 6.37 ; 6.80$ & $0.08 ; 0.12 ; 0.10$ \\
\hline T3 & $1.0 ; 0.8 ; 0.8$ & $2.0 ; 0.9 ; 0.8$ & $8.92 ; 6.40 ; 5.60$ & $0.16 ; 0.11 ; 0.08$ \\
\hline T4 & $0.5 ; 0.9 ; 1.0$ & $1.0 ; 1.0 ; 1.0$ & $4.58 ; 6.73 ; 6.80$ & $0.08 ; 0.12 ; 0.10$ \\
\hline T5 & $2.0 ; 1.4 ; 1.2$ & $4.0 ; 1.6 ; 1.2$ & $18.33 ; 10.60 ; 8.16$ & $0.34 ; 0.19 ; 0.12$ \\
\hline T6 & $1.5 ; 1.1 ; 1.0$ & $3.0 ; 1.3 ; 1.0$ & 14.33; 9.39; 9.16 & $0.26 ; 0.18 ; 0.13$ \\
\hline $\mathrm{T7}$ & $0.5 ; 0.6 ; 1.4$ & $1.0 ; 0.7 ; 1.4$ & $8.33 ; 7.61 ; 11.21$ & $0.15 ; 0.14 ; 0.16$ \\
\hline$\sum_{i=1}^{n} \sum_{j=1}^{m} M_{i}^{j}$ & & & $68.25 ; 55.70 ; 54.53$ & $1.25 ; 1.00 ; 0.80$ \\
\hline$\frac{1}{\sum_{j=1}^{m} M_{i}^{j}}$ & & & $0.02 ; 0.02 ; 0.01$ & \\
\hline
\end{tabular}

Source: own study

Then, using the formulas (4-7) the normalized vector was calculated, and next the greatest root cause of the threat for the analyzed workplace was specified. Then, the results of the calculations are shown in Table 4.

Table 4

Results of calculation by the FAHP method

\begin{tabular}{|c|c|c|c|c|c|c|c|c|c|}
\hline \multicolumn{2}{|c|}{ T1 } & \multicolumn{2}{|c|}{ T2 } & \multicolumn{2}{|c|}{ T3 } & \multicolumn{2}{|c|}{ T4 } & \multicolumn{2}{|c|}{ T5 } \\
\hline $\mathrm{T} 1 \geq \mathrm{T} 2$ & 1.00 & $\mathrm{~T} 2 \geq \mathrm{T} 1$ & 0.00 & $T 3 \geq T 1$ & 0.00 & $\mathrm{~T} 4 \geq \mathrm{T} 1$ & 0.00 & $\mathrm{~T} 5 \geq \mathrm{T} 1$ & 1.00 \\
\hline $\mathrm{T} 1 \geq \mathrm{T} 3$ & 1.00 & $\mathrm{~T} 2 \geq \mathrm{T} 3$ & 1.00 & $\mathrm{~T} 3 \geq \mathrm{T} 2$ & 0.00 & $\mathrm{~T} 4 \geq \mathrm{T} 2$ & 1.00 & $\mathrm{~T} 5 \geq \mathrm{T} 2$ & 1.00 \\
\hline $\mathrm{T} 1 \geq \mathrm{T} 4$ & 1.00 & $\mathrm{~T} 2 \geq \mathrm{T} 4$ & 1.00 & $\mathrm{~T} 3 \geq \mathrm{T} 4$ & 0.00 & $\mathrm{~T} 4 \geq \mathrm{T} 3$ & 1.00 & T5 $\geq$ T3 & 1.00 \\
\hline $\mathrm{T} 1 \geq \mathrm{T} 5$ & 0.00 & $\mathrm{~T} 2 \geq \mathrm{T} 5$ & 0.00 & T3 $\geq T 5$ & 0.00 & $\mathrm{~T} 4 \geq \mathrm{T} 5$ & 0.00 & $T 5 \geq T 4$ & 1.00 \\
\hline $\mathrm{T} 1 \geq \mathrm{T} 6$ & 0.00 & $\mathrm{~T} 2 \geq \mathrm{T} 6$ & 0.00 & $T 3 \geq T 6$ & 0.00 & $\mathrm{~T} 4 \geq \mathrm{T} 6$ & 0.00 & $\mathrm{~T} 5 \geq \mathrm{T} 6$ & 1.00 \\
\hline $\mathrm{T} 1 \geq \mathrm{T} 7$ & 1.00 & $\mathrm{~T} 2 \geq \mathrm{T} 7$ & 0.00 & $\mathrm{~T} 3 \geq \mathrm{T} 7$ & 0.00 & $\mathrm{~T} 4 \geq \mathrm{T} 7$ & 0.00 & $\mathrm{~T} 5 \geq \mathrm{T} 7$ & 1.00 \\
\hline Min. & 0.00 & Min. & 0.00 & Min. & 0.00 & Min. & 0.00 & Min. & 1.00 \\
\hline \multicolumn{2}{|c|}{ T6 } & \multicolumn{2}{|c|}{ T7 } & \multicolumn{6}{|c|}{ Results } \\
\hline$T 6 \geq T 1$ & 1.00 & $\mathrm{~T} 7 \geq \mathrm{T} 1$ & 0.00 & \multirow{2}{*}{\multicolumn{6}{|c|}{$W^{\prime}=[0.00 ; 0.00 ; 0.00 ; 0.00 ; 1.00 ; 0.00 ; 0.00]$}} \\
\hline $\mathrm{T} 6 \geq \mathrm{T} 2$ & 1.00 & $\mathrm{~T} 7 \geq \mathrm{T} 2$ & 1.00 & & & & & & \\
\hline$T 6 \geq T 3$ & 1.00 & $\mathrm{~T} 7 \geq \mathrm{T} 3$ & 1.00 & \multirow{2}{*}{\multicolumn{6}{|c|}{$\Sigma W^{\prime}=1.00$}} \\
\hline $\mathrm{T} 6 \geq \mathrm{T} 4$ & 1.00 & $\mathrm{~T} 7 \geq \mathrm{T} 4$ & 1.00 & & & & & & \\
\hline$T 6 \geq T 5$ & 0.00 & $\mathrm{~T} 7 \geq \mathrm{T} 5$ & 0.00 & \multirow{2}{*}{\multicolumn{6}{|c|}{$W n^{\prime}=[0.00 ; 0.00 ; 0.00 ; 0.00 ; 1.00 ; 0.00 ; 0.00]$}} \\
\hline $\mathrm{T} 6 \geq \mathrm{T} 7$ & 1.00 & $\mathrm{~T} 7 \geq \mathrm{T} 6$ & 0.00 & & & & & & \\
\hline Min. & 0.00 & Min. & 0.00 & \multicolumn{6}{|c|}{$\mathrm{MAX}=1.00=\mathrm{T} 5$} \\
\hline
\end{tabular}

Source: own study

After the calculation of integrated methods of PN-N-18002 and FAHP was made, it was shown that the largest threat on the loader operator, excavator operator and dredge operator was work at height (i.e. T5).

\section{DISCUSSION AND CONCLUSION}

Providing a safe and healthy workplace is realized among others by making an occupation risk assessment. In particular it is important in the cause of industrial 
enterprises, in which the number of accidents is the greatest. It was shown, that the method of occupational risk assessment, which is the most often used in mentioned industrial enterprises, is the PN-N-18002 method. However, this method was not improved in the context of achieving the precise results of the assessment. This was considered a research gap. Therefore, the aim is to improve the process of assessment in industrial enterprises by integrated the PN-N-18002 method with the FAHP method (Fuzzy Analytic Hierarchy Process).

The test of the proposed method was made for three machines, i.e.: loader operator ( $\measuredangle-$ 34), excavator operator (323) and dredge operator (300/250 KREBS 10/8). These machines were used to process of extraction of aggregates in one of Podkarpacie opencast enterprises. By integrated the methods of PN-N-18002 and the FAHP method, a precise indication of the source of threats was made, which is the greatest danger to the operators of the analyzed workstations. It was shown, that it is the work at height. It was concluded, that integration of the method of occupation risk assessment with the multicriteria decision method is effective and allows for precise making the risk assessment, and at the same time, it will contribute to increase the safety of life and health of employees. Furthermore, it was concluded, that this method can be practice to risk assessment of other workplaces, among others from industrial enterprises.

\section{REFERENCES}

Aagedal, J. O., den Braber, F., Dimitrakos, T. Gran, B. A., Raptis, D., Stolen, K., 2002. Model-based Risk Assessment to Improve Enterprise Security, IEEE, Proceedings. Sixth International Enterprise Distributed Object Computing, 51-62. DOI: 10.1109/EDOC.2002.1137696

Bajdur, W., Idzikowski, A., 2012. Analiza i ocena ryzyka zawodowego wybranych stanowisk pracy w zakładzie odkrywkowym dolomitu, PTZP, 691-702. Available: http://ptzp.org.pl/files/konferencje/kzz/artyk_pdf_2012/p062.pdf (04.11.2020)

Chang, D.Y. 1996. Application of the extent analysis method on fuzzy AHP, Eur. J. Oper. Res., 95(3), 649-655.

Chen, T., Wang, Y., Wang, J. et al., 2020. Multistage Decision Framework for the Selection of Renewable Energy Sources Based on Prospect Theory and PROMETHEE, International Journal of Fuzzy Systems, 22(5), 1535-1551. DOI: 10.1007/s40815-020-00858-1

Duda, A., Juzek, T., 2018. Ocena ryzyka zawodowego podczas czynności związanych z drążeniem przodka I zabudową obudowy, Systemy wspomagania w inżynierii produkcji, Górnictwo - perspektywy i zagrożenia. Węgiel, tania czysta energia i miejsca pracy, 7, 1, 329-340.

Gil, M.Á., González-Rodríguez, G., 2012. Fuzzy vs. Likert Scale in Statistics, Trillas E., Bonissone P., Magdalena L., Kacprzyk J. (Eds.), Combining Experimentation and Theory. Studies in Fuzziness and Soft Computing, 271, Springer, Berlin, Heidelberg. DOI: 10.1007/978-3-642-24666-1_27

GUS, 2020. Wypadki przy pracy w 2019 r. - dane wstępne. (03.11.2020).

Harabas, S., Klimecka-Tatar, D., 2017. Ocena ryzyka zawodowego na stanowisku operatora linii lakierniczej, Archiwum Wiedzy Inżynierskiej, 2(1), 26-31.

Karkoszka, T., 2009. Improvement of the chosen process based on the occupational health and safety criterion, Journal of Achievements in Materials and Manufacturing Engineering, 37(20), 735-742. 
Karkoszka, T., Szewieczek, D., 2007. Risk of the processes in the aspect of quality natural environment and occupational safety, Journal of Achievements in Materials and Manufacturing Engineering, 20(1-2), 539-542.

Krause, M. 2011. Praktyczne aspekty doboru metody oceny ryzyka zawodowego, Zeszyty Naukowe Politechniki Śląskiej. Organizacja i zarządzanie, 59, 173-190.

Krishankumar, R., Mishra, A. R., Ravichandran, K. S. et al., 2020. A Group Decision Framework for Renewable Energy Source Selection under Interval-Valued Probabilistic linguistic Term Set, Energies, 13(4). DOI: 10.3390/en13040986

Łuczak, A., 2012. Ocena ważności czynników strategicznych w gminie wiejskiej z wykorzystaniem rozmytego analitycznego procesu hierarchicznego, Journal of Agribusiness and Rural Development, 4(26), 43-56.

Mir, S.A., Padma, T., 2016. Evaluation and prioritization of rice production practices and constraints under temperate climatic conditions using Fuzzy Analytical Hierarchy Process (FAHP), Spanish Journal of Agricultural Research, 14(4). DOI: 10.5424/sjar/2016144-8699

Pacana, A., Czerwinska, K, Bednarova, L., 2018. Discrepancies analysis of casts of diesel engine piston, Metalurgija, 4(57), 324-326. DOI: https://hrcak.srce.hr/201754

Pacana, A., Siwiec, D., Bednarova, L. 2020. Method of Choice: A Fluorescent Penetrant Takinginto Account Sustainability Criteria, Sustainability, 12(14), 5854. DOI: $10.3390 /$ su 12145854

PN-N-18002:2011. Systemy zarządzania bezpieczeństwem i higieną pracy - Ogólne wytyczne do oceny ryzyka zawodowego.

Saja, P., Woźny, A., Pacana, A., Dobosz, M., 2013. Additional components of risk assessment and their impact on the probability parameter, Production Engineering Archives, 14, 11-14. DOI: 10.30657/pea.2017.14.03

Siwiec, D., Bednarova, L., Pacana, A., 2020. Metoda doboru penetrantów dla przemysłowych badań nieniszczących, Przemysł Chemiczny, 99(5), 771-773. DOI: DOI: 10.15199/62.2020.5.18

Siwiec, D., Bednarova, L., Pacana, A. et al., 2019. Decision support in the selection of fluorescent penetrants for industrial non-destructive testing, Przemysł Chemiczny, 98, 10, 1594-1596. DOI: 10.15199/62.2019.10.12

Solangi, Y.A., Longsheng, C., Shah, S.A., et al., 2020. Analyzing Renewable Energy Sources of a Developing Country for Sustainable Development: An Integrated Fuzzy Based-Decision Methodology, Processes, 8(7). DOI: 10.3390/pr8070825

Szklarzyk, P., Klimecka-Tatar, D., Kleszcz, D., 2016. Obowiązki prawne i systemowe w ocenie ryzyka zawodowego jako element zapewnienia odpowiedniego poziomu bezpieczeństwa I higieny pracy, Zeszyty Naukowe Quality.Production.Improvement, 1(4), 132-145.

Tsai, H.-C., Lee, A.-S., Lee, H.-N., Chen, C.-N., Liu, Y.-C., 2020. An Application of the Fuzzy Delphi Method and Fuzzy AHP on the Discussion of Training Indicators for the Regional Competition, Taiwan National Skills Competition, in the Trade of Joinery. Sustainability, 12(10), 4290. DOI: https://doi.org/10.3390/su12104290

Woźny, A., Pacana, A., 2017. Synthetische Auffassung der Methoden für Gefährdungsbeurteilung. Monographie. Euro-Capitol (F.Hadam, Freiligrath Str. 6, 88046 Friedrichschafen, Deutschland) ISBN 978-3-00-059231-7, Friedrichschafen (Deutschland).

Woźny, A., Saja, P., Pacana, A., Dobosz, M., 2016. Analiza ryzyka zawodowego na stanowisku kierowcy autobusu, Autobusy, Bezpieczeństwo i ekologia, 6, 488-492. 